\title{
SORPTION AND DESORPTION BEHAVIOR OF HERBICIDE CLOMAZONE IN SOILS FROM BRAZIL
}

\author{
COMPORTAMENTO DE SORÇÃO E DESSORÇÃO DO CLOMAZONE EM SOLOS \\ DO BRASIL
}

\begin{abstract}
Gustavo Antônio Mendes PEREIRA ${ }^{1}$; Dayana Alves RODRIGUES ${ }^{2}$; Letícia Assis Barony Valadares FONSECA ${ }^{3}$; Ana Beatriz Rocha de Jesus PASSOS ${ }^{1}$; Marcos Raphael Freitas da SILVA ${ }^{2}$; Daniel Valadão SILVA ${ }^{4}$; Antonio Alberto da SILVA ${ }^{5}$

1. Ph.D, Universidade Federal de Viçosa - UFV, Viçosa, Minas Gerais, Brasil, gustavogamp@ hotmail.com; 2. Ph.D, Universidade Federal de Viçosa - UFV, Viçosa, Minas Gerais, Brasil, 3. Graduate student, Universidade Federal de Viçosa (UFV), Viçosa, Minas Gerais, Brasil; 4. Ph.D, Professor, Universidade Federal Rural do Semi-Árido - UFERSA, Mossoró, Rio Grande do Norte, Brazil; 5.

Ph.D, Professor, Universidade Federal de Viçosa (UFV), Viçosa, Minas Gerais, Brasil,
\end{abstract}

\begin{abstract}
The knowledge of the processes that affect soil herbicide behavior allows to developing practices that improve efficiency in chemical weed control and reduce the negative impacts of cropping-systems. In this research, we used HPLC to determine sorption and desorption of clomazone in Brazilian soil samples (Red-Yellow Latosol with liming and without liming, Red latosol with and without liming, and Organosol). To study clomazone sorption, we used the batch equilibrium method. Clomazone concentrations in soil samples were determined by HPLC. Desorption was quantitated using the samples contained in tubes after sorption testing, repeating the steps followed to quantify sorption. The Freundlich isotherm adequately describe clomazone sorption in all soils. Variation in $\mathrm{pH}$ in Red-Yellow Latosol and Red Latosol did not change clomazone sorption. The values of the Freundlich constant (Kf) indicate that clomazone sorption is higher in Organosol, followed by Red latosol (with liming) = Red latosol (without liming) > Red-Yellow Latosol (with liming) = Red-Yellow Latosol (without liming). We conclude that among the attributes evaluated, soil organic matter has the highest impact on clomazone sorption. There was a direct relationship between Kf values and organic matter content of the substrates. Desorption of clomazone was very low in the evaluated soils, with the exception of Organosol, where quantification of the herbicide was possible.
\end{abstract}

KEYWORDS: Herbicides. Soil behavior. Environmental impact. HPLC.

\section{INTRODUCTION}

Chemical weed control is essential for largescale agriculture. However, it is crucial that the used herbicides are only recommended after evaluation of their interactions with soil colloids in ensure a high quality of the harvested product and the natural resources that sustain production, especially soil and water (SILVA et al, 2013). The use of pre-emergent herbicides with residual activity in the crop management operation has become a common practice to reduce the initial competition exerted by weeds. The application of these products has as main target the soil. Upon reaching the ground, soilapplied herbicides are redistributed and degraded this process can be short, as in the case of simple molecules which are not persistent or last for months or years in the case of highly persistent compounds. Residence time of herbicides in the environment depends, among other factors, on the sorption capacity of the soil, the dynamics of fluid flow, and the solute transport in addition to degradation rates. In areas with extensive and excessive herbicide use, environmental contamination may occur (CUMMING et al, 2002;
UMILJENDIĆ et al, 2013). Therefore, it is crucial to obtain more information on the dynamics of herbicides in the soil to improve herbicide efficacy and reduce the environmental problems caused using these products.Knowledge of the processes to which the molecules of herbicides are subject to after contact with the ground is critical to predict the herbicide's efficacy and the fate of these substances in the environment (SILVA et al, 2013).

Soil-herbicide interactions alter product availability in the soil solution and are governed by the retention processes of these compounds (GEVAO et al, 2000). The sorption process influences herbicide absorption by plant roots and dissipation processes such as biological degradation, volatilization, leaching, and transport by water erosion (HERWIG et al, 2001; GAVRILESCU, 2005). Sorption (the fractions of the herbicide connected to the soil) and desorption (percentage of the product sorbed which returns to the soil solution) are processes that influence leaching, persistence, and activity of the compound in the environment ( $\mathrm{YU}$ et al, 2006). These processes can be described by isotherms regarding concentrations in the solution and in the solid soil phase. 
The sorption isotherm describes the thermodynamic relationship between water activity and the equilibrium of the moisture content of a soil product at constant temperature and pressure. The knowledge and understanding of sorption isotherms is highly important in soil science and technology for the predictions of quality, stability, and half-life.

The extent to which this phenomenon occurs reflects the reversibility of the sorption process. In some cases, this can be very high, in others, sorption is almost irreversible (hysteresis (H)).

Clomazone [2-(2-Chlorobenzyl)-4,4dimethyl-1,2-oxazolidin-3-one] is an herbicide from the chemical group isoxazolidinone. Widely used in weed control in crops of mono- and eudicotyledons such as cotton, rice, potatoes, sugarcane, tobacco, and cassava, is used both as pre-emergent and postemergent. Clomazone is a non-ionizable herbicide and therefore remains in its molecular form in the soil solution (CAO et al, 2013). However, non-ionic herbicides may be polar and therefore affected by $\mathrm{pH}$ and complexes adsorbed to clay minerals and soil organic matter (SILVA et al, 2013). Organic matter is the primary attribute of the soil influence the sorption of clomazone (UMILJENDIĆ et al, 2013; GUNASEKARA et al, 2009). However, its role is dependent on its concentration in the soil and chemical composition can vary significantly and thus influence the nature and extent of herbicide sorption (ĐUROVIĆ-PEJČEV et al, 2008).

Considering the wide range of agricultural land in Brazil, studies of the clomazone sorption Brazilian soils are crucial for obtaining technical recommendations to ensure the agronomic efficiency of this herbicide along with low environmental risks for different soils and climates in Brazil. The aim of this study was to evaluate sorption and desorption capacity of clomazone in three Brazilian soils with different characteristics, using high-performance liquid chromatography

\section{MATERIAL AND METHODS}

\section{Soil Samples}

The experiment was conducted with three soils from distinct Brazilian regions: Red-Yellow Latosol from the state of Tocantins, Red Latosol from the state of Minas Gerais, and Organosol from the state of Espírito Santo. Each Latosol sample was divided into two parts: One sample was limed to reach a soil $\mathrm{pH}$ in the neutral range (Table 1). Soil samples were collected from the surface layer (at a depth of 0.0 to $0.20 \mathrm{~m})$, dried in the shade $\left(25^{\circ} \mathrm{C}\right)$, sieved through a 2-mm mesh and subsequently characterized chemically and physically (Tables 1 and 2). Acidity correction was performed by acid neutralization curves adding $\mathrm{CaCO}_{3}$ samples.

Table 1. Results of the chemical analysis of substrate samples A (Red-Yellow Latosol, $\mathrm{pH}=6.5$ ), B (RedYellow Latosol, $\mathrm{pH}=5.7$ ), $\mathrm{C}$ (Red Latosol, $\mathrm{pH}=6.5$ ), $\mathrm{D}$ (Red Latosol, $\mathrm{pH}=5.1$ ), and $\mathrm{E}$ (Organosol, $\mathrm{pH}=5.32)$

\begin{tabular}{llllllllll}
\hline & $\mathrm{pH}$ & $\mathrm{K}$ & $\mathrm{Ca}$ & $\mathrm{Mg}$ & $\mathrm{Al}$ & $\mathrm{H}+\mathrm{Al}$ & $\mathrm{SB}^{(\mathrm{a})}$ & $(\mathrm{t})$ & $\mathrm{OM}^{(\mathrm{b})}$ \\
\cline { 3 - 7 } Substrate & $\mathrm{H}_{2} \mathrm{O}$ & \multicolumn{2}{l}{$\mathrm{cmol}_{\mathrm{c}} \mathrm{kg}^{-1}$} & & & & & & $\%$ \\
A & 6.50 & 79 & 1.30 & 0.70 & 0.0 & 4.50 & 33.50 & 2.30 & 3.0 \\
$\mathrm{~B}$ & 5.70 & 79 & 0.99 & 0.52 & 0.0 & 4.70 & 26.70 & 1.71 & 3.0 \\
$\mathrm{C}$ & 6.50 & 9 & 0.34 & 0.15 & 0.0 & 2.52 & 60.00 & 0.79 & 2.1 \\
$\mathrm{D}$ & 5.10 & 9 & 0.04 & 0.06 & 1.6 & 5.30 & 2.90 & 1.66 & 2.1 \\
E & 5.32 & 185 & 5.10 & 3.00 & 0.6 & 26.64 & 31.00 & 9.17 & 20.2 \\
\hline
\end{tabular}

Table 2. Results of the physical analysis of substrate samples A (Red-Yellow Latosol, pH =6.5), B (RedYellow Latosol, $\mathrm{pH}=5.7), \mathrm{C}($ Red Latosol, $\mathrm{pH}=6.5), \mathrm{D}($ Red Latosol, $\mathrm{pH}=5.1$ ) and $\mathrm{E}$ (Organosol, $\mathrm{pH}=5.32$ ).

\begin{tabular}{lccc}
\hline Substrate* & Sand $\%$ & Silt $\%$ & Clay \% \\
\hline A & 55 & 30 & 39 \\
B & 55 & 30 & 39 \\
C & 21 & 10 & 62 \\
D & 21 & 10 & 62 \\
E & 34 & 20 & 36
\end{tabular}

*Analyses carried out in the Laboratory of Analysis of Soil Viçosa, according to the methodology of the Empresa Brasileira de Pesquisa Agropecuária-EMBRAPA (Brazilian Agricultural Research Corporation). 


\section{Herbicide, Chemicals and Sorption equilibrium time}

Determination of the sorption equilibrium time of clomazone by soil colloids was performed using the batch equilibrium method. For this, a solution containing $2.5 \mathrm{mg} \mathrm{L}^{-1}$ clomazone obtained from a stock-solution of $1.000 \mathrm{mg} \mathrm{L}^{-1}$ clomazone Pestanal ${ }^{\circledR}$ (Sigma Chem. Co., Standard Analytical 99.7\% purity) in $\mathrm{CaCl}_{2} 0.01 \mathrm{~mol} \mathrm{~L}^{-1}$ was prepared. Then, $10 \mathrm{~mL}$ of this solution and $2.0 \mathrm{~g}$ of each soil sample were added to polypropylene tubes. The tubes were properly sealed and placed vertically under agitation for different time periods $(0.0,0.5$, 1.0, 2.0, 4.0, 8.0, 12.0, 16.0, 24.0, and 28.0 hours) at room temperature $\left(25 \pm 2{ }^{\circ} \mathrm{C}\right)$. After agitation, samples were centrifuged at $2,260 \mathrm{x} g(3,500 \mathrm{rpm})$ for seven minutes. Part of the supernatant was filtered through a Millipore filter with a $0.45 \mu \mathrm{m}$ Politetrafluoretileno (PTFE) membrane and placed directly in a bottle with a capacity of $0.0015 \mathrm{~L}$ for subsequent analysis by high-performance liquid chromatography (HPLC). For this experiment, we considered that equilibration time of the analyzed concentration of the solution remained constant.

\section{Sorption/Desorption Experiments}

Sorption analysis was performed using working solutions from the same stock-solution at concentrations of $0.5,1.0,2.5,5.0$, and $10.0 \mathrm{mg} \mathrm{L}^{-1}$ of clomazone in $0.01 \mathrm{~mol} \mathrm{~L}^{-1} \mathrm{CaCl}_{2}$. We added 0.01 $\mathrm{L}$ of these solutions to tubes containing $2.0 \mathrm{~g}$ of soil. Then, the tubes were subjected to vertical stirring at room temperature to determine equilibration time. After agitation, samples were centrifuged at 2,260 x $\mathrm{g}(3,500 \mathrm{rpm})$ for seven minutes. A portion of the supernatant was filtered through a $0.45 \mu \mathrm{m}$ membrane and transferred into $0.0015 \mathrm{~L}$ vials for HPLC analysis.

Desorption was performed immediately after sorption at all points of the sorption isotherms. The adsorption from the supernatant was completely removed and we subsequently added $\mathrm{CaCl}_{2} \quad 0.01$ mol L ${ }^{-1}$ of free herbicide until reaching the initial root weight. All replacement volumes were evaluated by weighing on a precision scale $(0.1 \mathrm{mg})$ and ranged from 0.077 to $0.094 \mathrm{~L}$. The vials were agitated to disperse the agglomerated soil and the suspensions were shaken mechanically for the determined equilibration time at room temperature. The suspensions were then centrifuged at $3500 \mathrm{rpm}$ (for 7 minutes) and the supernatants were filtered and analyzed by HPLC. The amount of herbicide still sorbed in the soil in each desorption phase was calculated as the difference between the quantity of sorbed and desorbed herbicide.

\section{Clomazone Extraction and Analysis}

Quantification of clomazone was carried out using a liquid chromatograph with high efficiency (Shimadzu LC 20AT, Japan model), a photodiode array detector (Shimadzu SPD- M20A), and a stainless steel C18 column (Shimadzu VP-ODS Shim-pack $250 \mathrm{~mm}$ x $4.6 \mathrm{~mm}$ ID, $5 \mu \mathrm{m}$ particle size). The chromatographic conditions were a mobile phase of acetonitrile: water (acidified with $0.01 \% \mathrm{v} / \mathrm{v}$ orthophosphoric acid) at a ratio of 50:50, injection volume of $20 \mu \mathrm{L}$, flow of $0.0012 \mathrm{~L} \mathrm{~min}^{-1}$ wavelength of $194 \mathrm{~nm}$, and a temperature of $30^{\circ} \mathrm{C}$ column. Under these conditions, the retention time for clomazone was approximately 10 minutes. Comparison of retention time of the sample with an analytical standard clomazone allowed herbicide identification, quantification was determined by the external calibration method.

\section{Data Analysis}

The Freundlich isotherm is used to describe this phenomenon, the empirical adjustments Cs and Ce refer to herbicide concentrations that are sorbed to the soil and the concentration remaining in solution after the equilibration period, respectively. This adjustment produces $\mathrm{Kf}$ coefficients and $1 / \mathrm{n}$. The Freundlich coefficient (Kf) indicates the strength of the sorption while $1 / \mathrm{n}$ indicates the nonlinearity of the sorption and desorption isotherm according to Equation 1 (OLIVEIRA, 2002).

$$
\mathrm{Cs}=\mathrm{Kf}^{*} \mathrm{Ce}^{1 / \mathrm{n}}
$$

The concentration of sorbed herbicide (Cs) in $\mathrm{mg} \mathrm{kg} \mathrm{kg}^{-1}$ was calculated from the difference between the standard solutions initially added to the soil $(\mathrm{Cp})$ in $\mathrm{mg} \mathrm{L}^{-1}$ and the amount found in the equilibrium solution $(\mathrm{Ce})$ in $\mathrm{mg} \mathrm{L}^{-1}$. The Freundlich equation was used to interpret the results of sorption and desorption based on the values of $\mathrm{Cs}$ and $\mathrm{Ce}$.

The method for determining sorption and desorption was validated according to parameter selectivity, linearity, limit of detection, and quantification. Linearity was determined using seven concentrations in triplicate from 0.05 to 1.1 $\mathrm{mg} \mathrm{L}^{-1} \mathrm{CaCl}_{2} 0.01 \mathrm{~mol} \mathrm{~L}^{-1}$. Selectivity was assessed by assaying the supernatants resulting from the agitation of soil with $0.01 \mathrm{~L}$ of $\mathrm{CaCl}_{2}$ solution 0.01 $\mathrm{mol} \mathrm{L}{ }^{-1}$ for the presence of free clomazone.

Limit of detection (LD) and limit of quantification (LQ) were determined using the method based on the analytical curve parameters, where these parameters are expressed by $3.3 \times(\mathrm{s} / \mathrm{S})$ and $10 \mathrm{x}(\mathrm{s} / \mathrm{S})$, respectively, where ' $\mathrm{s}$ ' is the estimated standard deviation of the response, which can be the estimate of the standard linear equation coefficient, and ' $\mathrm{S}$ ' is the inclination or slope of the 
calibration curve deviation (RIBANI et al, 2004). Pearson correlations were also performed between the studied attributes and $\mathrm{Kf}$ observed. In addition, we compared the estimates of the $\mathrm{Kf}$ parameter values with their respective confidence intervals, using the R software (Version 0.99.896 - (C) 20092016 RStudio, Inc.) with the help of the package 'nlme'.

\section{RESULTS AND DISCUSSION}

\section{Sorption equilibrium time}

The sorption of clomazone reached equilibrium after eight hours of agitation for some soils (Figure 1). However, the substrates were stirred for 12 hours to ensure equilibration.

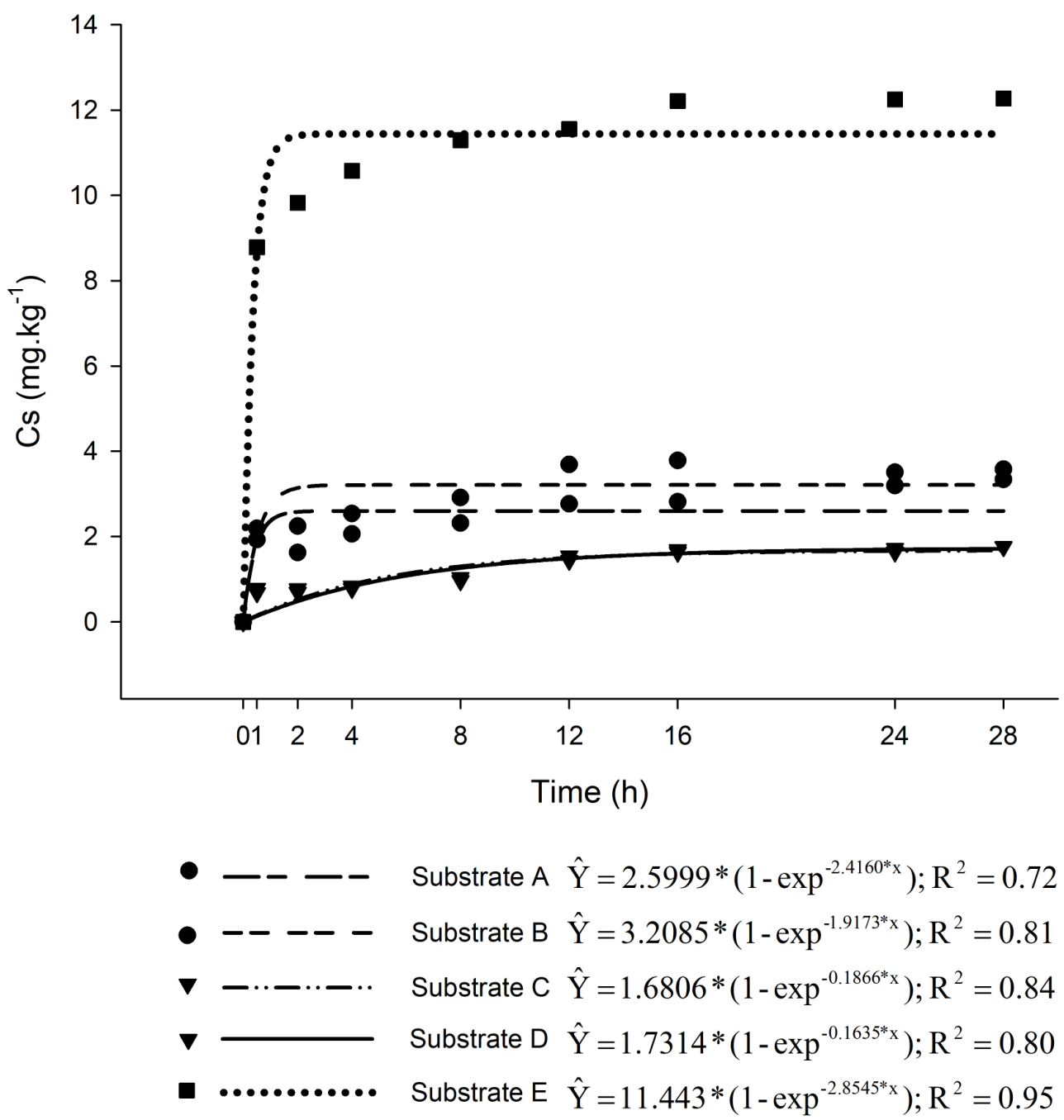

Figure 1. Kinetic curve of clomazone sorption in the substrate A (Red-Yellow Latosol, $\mathrm{pH}=6.5$ ), B (RedYellow Latosol, $\mathrm{pH}=5.7), \mathrm{C}($ Red Latosol, $\mathrm{pH}=6.5), \mathrm{D}($ Red Latosol, $\mathrm{pH}=5.1)$ and $\mathrm{E}$ (Organosol, $\mathrm{pH}=5.32$ ).

In all substrates, sorption kinetics were characterized by two phases: rapid sorption at the initial stage, the first four hours, followed by a slower phase (PASSOS et al. 2013). Also observed the for atrazine and 2,4-D, reporting that $90 \%$ of the compounds sipped the first four hours under stirring, followed by a slower subsequent sorption and an equilibrium. This result can be explained by the fact that in the first hour, many sorption sites on the ground and in the next phase are available, albeit the vacant surface sites are difficult to be occupied due to the repulsive forces between the molecules of the solute in the solid phase and molecules in solution (LIU et al, 2010; ROCHA et al, 2013).

The method is selective because there are not interfering in the retention time of the analyte and obtaining good linearity $(y=118883 \mathrm{x}+5687.8)$ with a coefficient of determination of 0.99 . The limits of detection and quantification were 0.35 and $1.07 \mathrm{mg} \mathrm{kg}^{-1}$, respectively. 


\section{Sorption Isotherm}

The Freundlich isotherm was adjusted appropriately to describe sorption of clomazone to the substrates studied, as indicated by the
PEREIRA, G. A. M. et al

determination coefficients of the equations $\left(\mathrm{r}^{2}=\right.$ 0.73 to 0.99 ) (Figure 2). The Kf values ranged from 1.48 to 22.12 (Table 3 ).

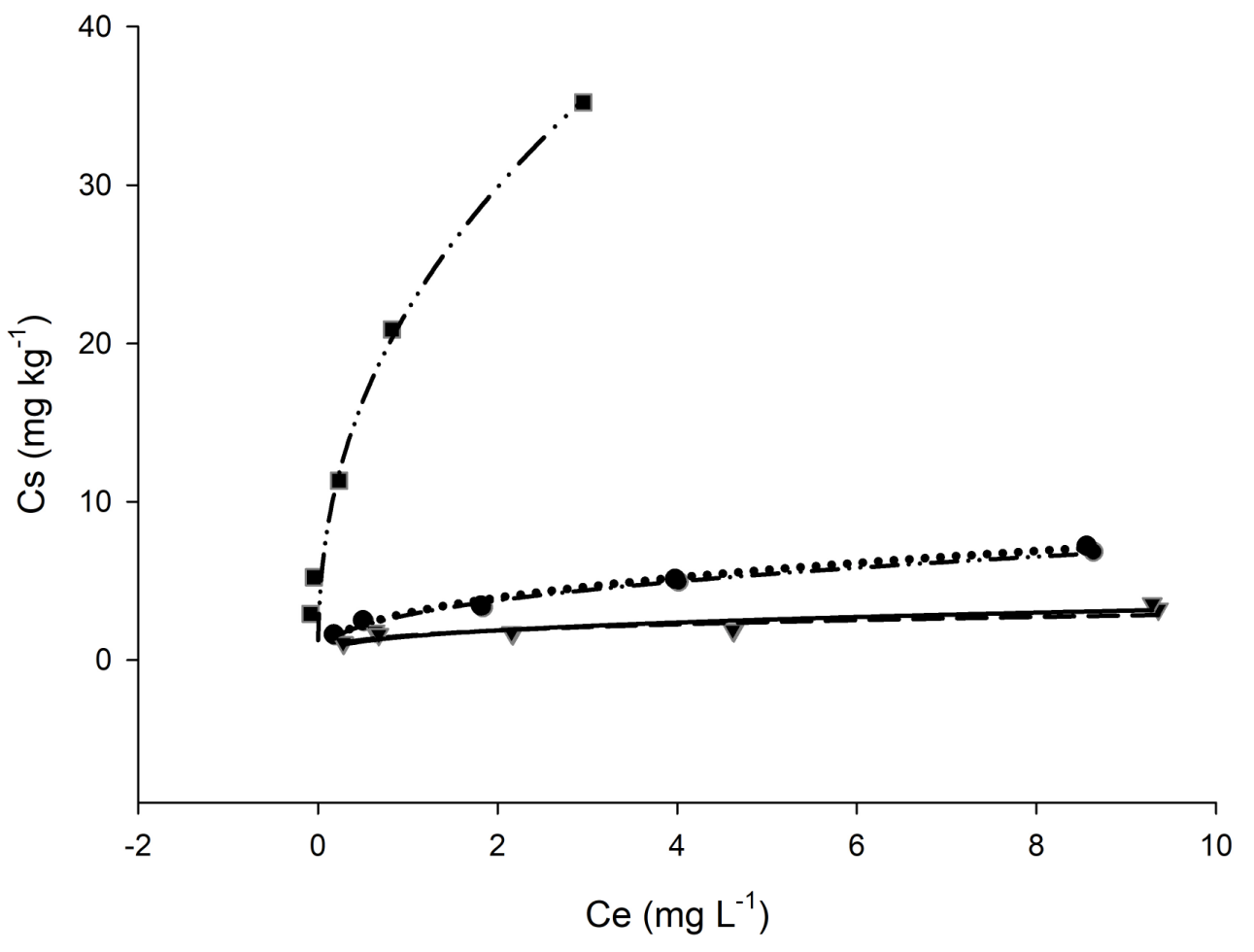

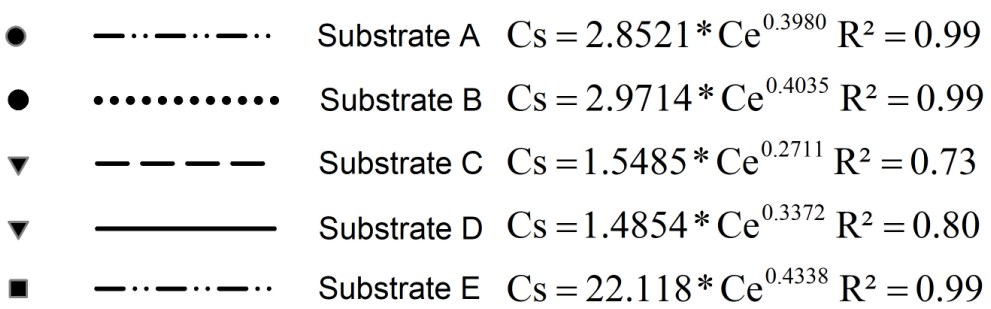

Figure 2. Clomazone of sorption isotherms in the substrate A (Red-Yellow Latosol, $\mathrm{pH}=6.5$ ), B (Red-Yellow Latosol, $\mathrm{pH}=5.7), \mathrm{C}$ (Red Latosol, $\mathrm{pH}=6.5), \mathrm{D}($ Red Latosol, $\mathrm{pH}=5.1)$, and $\mathrm{E}($ Organosol, $\mathrm{pH}=$ 5.32).

Table 3. Parameters of clomazone sorption of Freundlich equation in the substrate A (Red-Yellow Latosol, $\mathrm{pH}$ $=6.5), \mathrm{B}($ Red-Yellow Latosol, $\mathrm{pH}=5.7), \mathrm{C}($ Red Latosol, $\mathrm{pH}=6.5), \mathrm{D}($ Red Latosol, $\mathrm{pH}=5.1)$ and $\mathrm{E}($ Organosol, $\mathrm{pH}=5.32)$.

\begin{tabular}{lccccc}
\hline \multirow{2}{*}{ Parameters } & Substrate & \multicolumn{1}{l}{} \\
\cline { 2 - 6 } & $\mathrm{A}$ & $\mathrm{B}$ & $\mathrm{C}$ & $\mathrm{D}$ & $\mathrm{E}$ \\
\hline $\mathrm{Kf}$ & 2.8521 & 2.9714 & 1.5485 & 1.4854 & 22.118 \\
$1 \mathrm{n}^{-1}$ & 0.3980 & 0.4035 & 0.2711 & 0.3372 & 0.4338 \\
$\mathrm{R}^{2}$ & 0.99 & 0.99 & 0.73 & 0.80 & 0.99 \\
\hline
\end{tabular}

The $\mathrm{pH}$ variations in Latosols did not change the clomazone sorption (Figure3). The Kf values confirm that clomazone was more sorbed in Organosol, followed by Red-Yellow Latosol $(\mathrm{pH}=5.7)=$ Red-Yellow Latosol $(\mathrm{pH}=6.5)>$ Red Latosol $(\mathrm{pH}=6.5)=\mathrm{Red}$ Latosol $(\mathrm{pH}=5.1)$. Organic matter content and soil CTC decreased in the same order, confirming the results of the correlation between the attributes of substrates and $\mathrm{Kf}$ values (Table 4). The other attributes were not correlated with the Kf values. 
Organic matter contents of latosols were smaller to the Organosol, and clomazone sorption was lower in latosols (Fgure 3 and Table 4). These results can be explained by the influence of organic matter on the sorption of non-ionic molecules, such as clomazone (UMILJENDIĆ et al, 2013; BENOIT et al, 2008). Several studies demonstrated a direct relationship between clomazone sorption and soil organic matter (UMILJENDIĆ et al, 2013; BENOIT et al, 2008; SILVA et al, 2012).

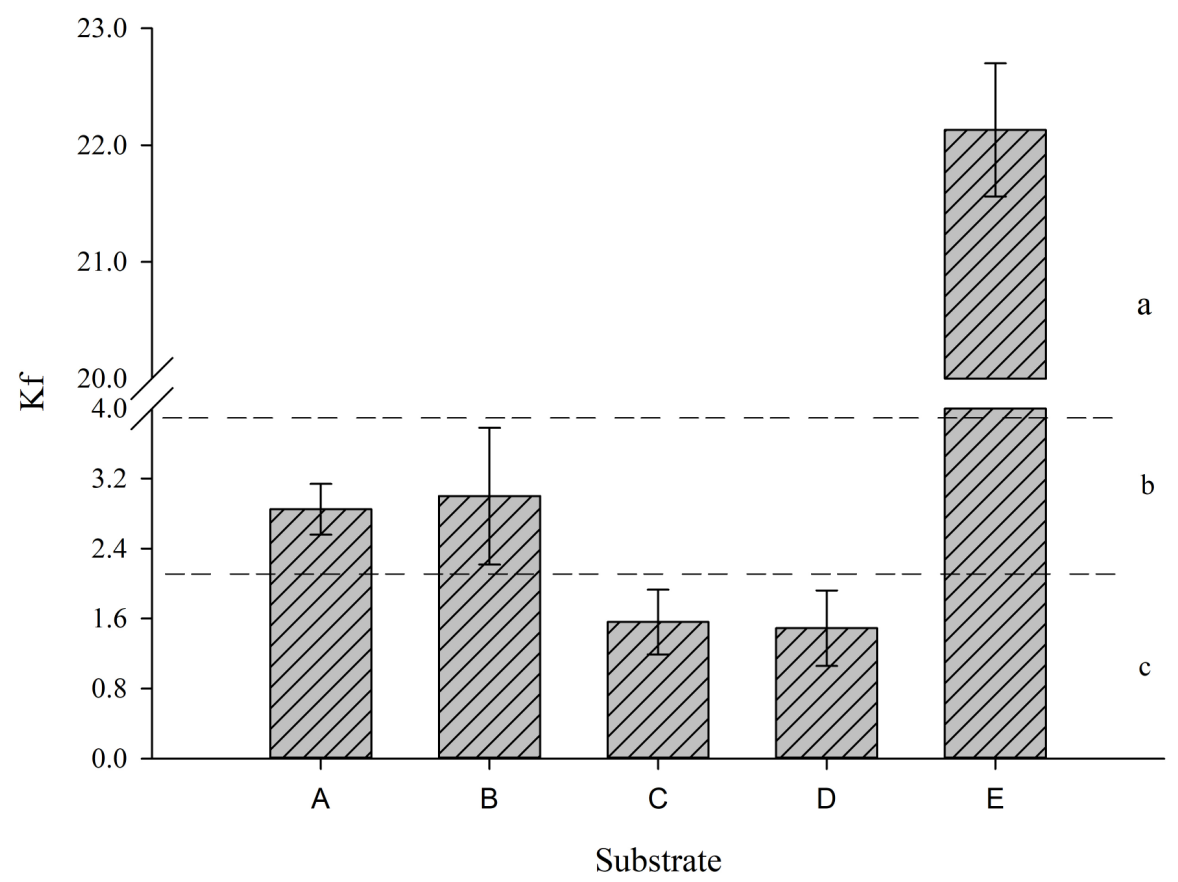

Figure 3. Parameter estimates "Kf" and it confidence intervals for the substrates A (Red-Yellow Latosol, $\mathrm{pH}=$ 6.5), B (Red-Yellow Latosol, $\mathrm{pH}=5.7), \mathrm{C}$ (Red Latosol, $\mathrm{pH}=6.5)$, D (Red Latosol, $\mathrm{pH}=5.1$ ) and $\mathrm{E}$ (Organosol, $\mathrm{pH}=5.32$ ). Confidence intervals separated by dashed lines and identified by different lower case letters are statistically different.

Table 4. Correlations between soil (organic matter, clay, silt, sand, $\mathrm{pH}$ and $\mathrm{CTC}$ ) and $\mathrm{Kf}$ values in the substrate A (Red-Yellow Latosol, $\mathrm{pH}=6.5$ ), B (Red-Yellow Latosol, $\mathrm{pH}=5.7), \mathrm{C}($ Red Latosol, $\mathrm{pH}=6.5), \mathrm{D}$ (Red Latosol, $\mathrm{pH}=5.1$ ) and $\mathrm{E}$ (Organosol, $\mathrm{pH}=5.32$ ).

\begin{tabular}{l|ccccccc}
\hline & OM & Clay & Silt & Sand & $\mathrm{pH}$ & \multicolumn{1}{l}{ CTC } & Kf \\
\hline OM & 1 & -0.54 & 0.06 & -0.05 & -0.41 & $0.99^{* *}$ & $0.99^{* *}$ \\
Clay & & 1 & $-0.87^{* *}$ & $-0.81^{* *}$ & 0.01 & -0.58 & -0.56 \\
Silt & & & 1 & 0.99 & 0.23 & 0.11 & 0.08 \\
Sand & & & & 1 & 0.27 & 0.01 & -0.03 \\
pH & & & & & 1 & -0.44 & -0.41 \\
CTC & & & & & & 1 & $0.99^{* *}$ \\
Kf & & & & & & & 1 \\
\hline
\end{tabular}

** significance $1 \%$ error probability.

\section{Desorption Isotherm}

The Kf value of desorption for Organosol (with higher organic matter contents) was higher than $\mathrm{Kf}$ or desorption (Figure 4) indicating that desorption was hindered by the strong interaction between organic matter and clomazone (VIEIRA et al, 1999). Several soil characteristics can affect herbicide sorption with organic matter, such as the source material, predominant types of minerals in the clay fraction, the presence of saturating ions of functional groups of organic matters, and specific ions (SILVA et al, 2013). 

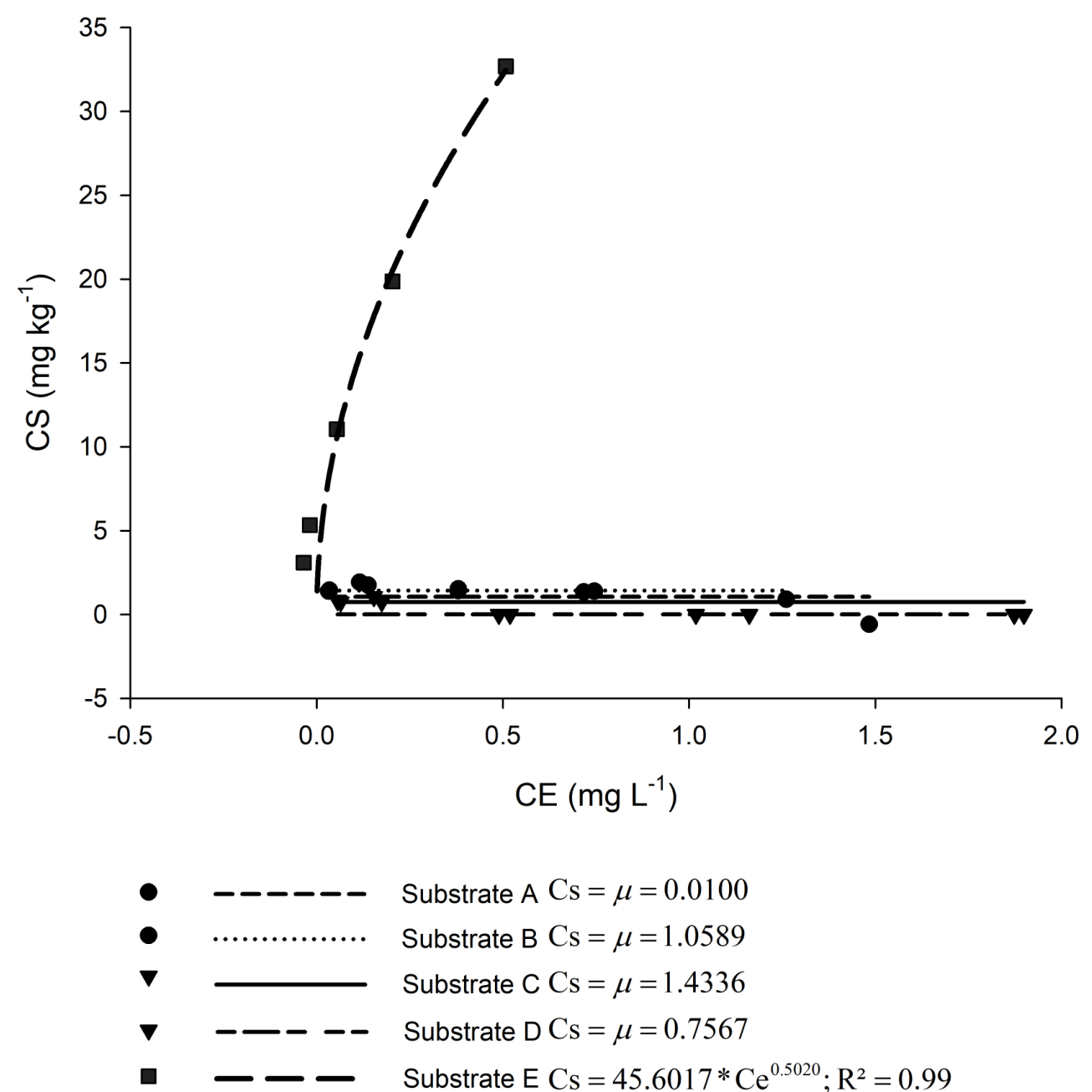

Figure 4. Desorption isotherms of clomazone in substrate A (Red-Yellow Latosol, $\mathrm{pH}=6.5$ ), $\mathrm{B}$ (Red-Yellow Latosol, $\mathrm{pH}=5.7), \mathrm{C}$ (Red Latosol, $\mathrm{pH}=6.5), \mathrm{D}$ (Red Latosol, $\mathrm{pH}=5.1)$, and $\mathrm{E}$ (Organosol, $\mathrm{pH}=$ 5.32)

Clomazone desorption for other substrates could not be quantified, possibly to the low $\mathrm{Kf}$ values observed in these substrates. As sorption was too low, the desorption of the remaining clomazone, irrespective of the concentration used in this study, was not significant, which prevented the use of the Freundlich isotherm model.

\section{CONCLUSION}

Organosol presents higher sorption capacity of clomazone. The results confirm the importance of knowledge of the physical and chemical characteristics of the soil, especially the organic matter content, before recommending the use of the herbicide clomazone. Information on the soil characteristics is crucial to make safe recommendations from an agronomic and environmental point of view.

\section{ACKNOWLEDGMENTS}

This work was supported by the Coordenação de Aperfeiçoamento e Pessoal de Nível Superior (CAPES) and Fundação de Amparo à Pesquisa do Estado de Minas Gerais (FAPEMIG).

RESUMO: O conhecimento dos processos que afetam o comportamento de herbicidas no solo permite desenvolver práticas que melhorem a eficiência no controle químico de plantas daninhas e reduzam os impactos negativos do seu uso em sistemas agrícolas. Nesta pesquisa, utilizando a cromatografia líquida de alta eficiência, foram determinadas a sorção e dessorção do clomazone em amostras de solos do Brasil (Latossolo VermelhoAmarelo com e sem calagem, 
Latossolo Vermelho com e sem calagem, e Organossolo). Para o estudo da sorção do clomazone foi utilizado o método Batch Equilibrium. As concentrações do clomazone nas soluções das amostras dos solos foram determinadas por cromatografia líquida de alta eficiência após centrifugação e filtração das soluções. A dessorção foi quantificada utilizando as amostras contidas nos tubos, após os ensaios de sorção repetindo-se os passos seguidos para quantificar a sorção. A isoterma de Freundlich ajustou-se adequadamente para descrever a sorção do clomazone em todos os solos estudados. As variações de pH nos Latossolo Vermelho-Amarelo e Latossolo Vermelho não alteraram a sorção do clomazone. Os valores de Kf indicam que oclomazone é mais sorvido no Organossolo seguindo a sorção em ordem decrescente para Latossolo Vermelho-Amarelo, Latossolo Vermelho-Amarelo (com calagem), Latossolo Vermelho e Latossolo Vermelho (com calagem). Concluiu-se que dentre os atributos dos solos avaliados a matéria orgânica foi o que mais influenciou a sorção do clomazone. Observou-se relação direta entre valores de $\mathrm{Kf}$ e teores de matéria orgânica nos substratos. A dessorção do clomazone foi muito baixa nos solos avaliados, com excessão do Organossolo, onde foi possível a quantificação do herbicida.

PALAVRAS-CHAVES: Herbicidas. Comportamento do solo. Impactos ambientais. HPLC.

\section{REFERENCES}

BENOIT, P.; MADRIGAL, I.; PRESTON, C. M.; CHENU, C.; BARRIUSO, E. Sorption and desorption of non-ionic herbicides onto particulate organic matter from surface soils under different land uses. Eur. J. Soil Sci. 2008. v. 59, n. 1, p. 178-189. https://doi.org/10.1111/j.1365-2389.2007.00967.x

CAO, J. I. A., XIAO-PING, D. I. A. O.; JI-YE, H. U. Hydrolysis and Photolysis of Herbicide Clomazone in Aqueous Solutions and Natural Water Under Abiotic Conditions. J. of Int. Agr. 2013. v. 12, n. 11, p. 20742082. https://doi.org/10.1016/S2095-3119(13)60506-7

CUMMING, J. P.; DOYLE, R. B.; BROWN, P. H. Clomazone dissipation in four Tasmanian topsoils. Weed Sci. 2002. v. 50, n. 3, p. 405-409. https://doi.org/10.1614/0043-1745(2002)050[0405:CDIFTT]2.0.CO;2

ĐUROVIĆ-PEJČEV, R.; GAJIĆ-UMILJENDIĆ, J.; ĐORĐEVIĆ, T. Determination of atrazine, acetochlor, clomazone, pendimethalin and oxyfluorfen in soil by solid phase microextraction method. Pestic. Phytomed. 2008. v. 23, n. 1, p. 153-166.

GAVRILESCU, M. Fate of pesticides in the environment and its bioremediation. Eng. Life Sci. 2005. v. 5, n. 6, p. 497-526. https://doi.org/10.1002/elsc.200520098

GEVAO, B.; SEMPLE, K.T.; JONES, K.C. Bound pesticide residues in soils: A review. Environ. Pollut. 2000. v. 108, n. 1, p. 3-14. https://doi.org/10.1016/S0269-7491(99)00197-9

GUNASEKARA, A. S.; DELA CRUZ, I. D.; CURTIS, M. J.; CLAASSEN, V. P.; TJEERDEMA, R. S. The behavior of clomazone in the soil environment. Pest Manag. Sci. 2009. v. 65, n. 6, p. 711-716. https://doi.org/10.1002/ps.1733

HERWIG, U.; NARRES, H. D.; SCHWUGER, M. J. Physicochemical interactions between atrazine and clay minerals. Applied Clay Sci. 2001. v. 18, n. 1, p. 201-222. https://doi.org/10.1016/S0169-1317(01)00024-2

LIU, Y.; XU, Z.; WU, X.; GUI, W.; ZHU, G. Adsorption and desorption behavior of herbicide diuron on various Chinese cultivated soils. J. Hazard Mater 2010. v. 178, n. 1, p. 462-468. https://doi.org/10.1016/j.jhazmat.2010.01.105

OLIVEIRA JR., R.S. Conceitos importantes no estudo do comportamento de herbicidas no solo. Boletim SBCS 2002. v. 27, n. 1, p. 9-13. 
PASSOS, A. B. R. J.; FREITAS, M. A. M.; TORRES, L. G.; SILVA, A. A.; QUEIROZ, M. E. L. R.; LIMA, CLÁUDIO F. Sorption and desorption of sulfentrazone in Brazilian Soils. Journal of Environmental Science and Health, Part B: Pesticides, Food Contaminants, and Agricultural Wastes. 2013. v. 48, p. 646-650. https://doi.org/10.1080/03601234.2013.777313

RIBANI, M.; BOTTOLI, C. B. G.; COLLINS, C. H.; JARDIM, I. C. S. F.; MELO, L. F. C. Validation for chromatographic and electrophoretic methods. Quím. Nova 2004. v. 27, n. 5, p. 771-780.

https://doi.org/10.1590/S0100-40422004000500017

ROCHA, P. R. R.; FARIA, A. T.; BORGES, L. G. F. C.; SILVA, L. O. C.; SILVA, A. A.; FERREIRA, E. A. Sorção e dessorção do diuron em quatro latossolos brasileiros. Plant. Dan. 2013. v. 31, n. 1, p. 231-238. https://doi.org/10.1590/S0100-83582013000100025

SILVA, A. A.; VIVIAN, R.; OLIVEIRA JR., R.S. Herbicidas: comportamento no solo, In: Tópicos em manejo de plantas daninhas; Silva, A. A., Silva, J. F., Eds.; Universidade Federal de Viçosa: Viçosa, 2013. p. 189-248.

SILVA, M. S.; COCENZA, D. S.; ROSA, A. H.; FRACETO, L. F. Efeito da associação do herbicida clomazone a nanoesferas de alginato/quitosana na sorção em solos. Quím. Nova 2012. v. 35, n. 1, p. 102-107. https://doi.org/10.1590/S0100-40422012000100019

UMILJENDIĆ, J. G.; RADIVOJEVIĆ, L.; TIJANA ĐORĐEVIĆ, T.; JOVANOVIĆ-RADOVANOV, K.; ŠANTRIĆ, L.; ĐUROVIĆ-PEJČEV, R.; ELEZOVIĆ, I. Bioassay technique to study clomazone residues in Sandy loam soil. Pestic. Phytomed. (Belgrade) 2013. v. 28, n. 3, p. 203-211.

https://doi.org/10.2298/PIF1303203G

VIEIRA, E. M.; PRADO, A. G. S.; LANDGRAF, M. D.; REZENDE, M. O. O. Estudo da adsorção/dessorção do ácido 2,4-diclorofenoxiacético (2,4-D) em solo na ausência e presença de matéria orgânica. Quím. Nova 1999. v. 22, n. 3, p. 305-308. https://doi.org/10.1590/S0100-40421999000300001 https://doi.org/10.1590/S0100-40421999000300002

YU, Y. L.; WUB, X. M.; LIA, S. N.; FANGA, H.; ZHANA, H. Y.; YU, J. Q. An exploration of the relationship between adsorption and bioavailability of pesticides in soil to earthworm. Environ. Pollut. 2006. v. 141, n. 3, p. 428-433. https://doi.org/10.1016/j.envpol.2005.08.058 